Joko Winarno dan Rusdiyantoro : Rancang Bangun Mesin Irat Bambu Untuk Pembuatan Jeruji Sangkar Burung Dan Tusuk Sate

\title{
RANCANG BANGUN MESIN IRAT BAMBU UNTUK PEMBUATAN JERUJI SANGKAR BURUNG DAN TUSUK SATE
}

\author{
Joko Winarno'), dan Rusdiyantoro ${ }^{2)}$ \\ ${ }^{1)}$ dan 2) Program Studi Teknik Industri, Fakultas Teknologi Industri (FTI) \\ Universitas PGRI Adi Buana Surabaya \\ Email: ejouko@yahoo.co.id
}

\begin{abstract}
Abstrak
Pembuatan jeruji sangkar burung secara manual sangat tidak efektif dan efisien karena membutuhkan waktu yang lama dan presisi yang rendah serta keseragaman ukuran tidak akurat. Metode yang digunakan saat penelitian adalah quality function development dimana metode tersebut digunakan untuk menentukan desain serta spesifikasi mesin yang sesuai dengan keinginan atau permintaan konsumen guna mendapatkan hasil yang sesuai keinginan konsumen. Teknik analisa penelitian ini menggunakan independent sampel t-test comperative dengan menggunakan aplikasi SPSS pada komputer. Metode independen sample t-test adalah metode atau prosedur yang digunakan untuk membandingkan rata-rata dua variabel dalam satu grup, artinya ini berguna untuk melakukan pengujian terhadap dua sampel yang berpasangan. Berdasarkan hasil uji independent sampel t-test comperative bahwa ad perubahan yang menonjol pada waktu penyerutan antara penyerutan secara manual dengan menggunakan mesin penyerut otomatis. Probabilitas (sig) 0,000 < 0,05 maka Ho ditolak, atau rata-rata hasil waktu dalam penyerutan bambu secara manual dengan secara otomatis berbeda signifikan. Artinya hasil waktu penyerutan secara manual lebih lama dibandingkan dengan waktu menggunakan otomatis. Dalam pengujian penyerutan bambu dengan panjang $60 \mathrm{~cm}$ secara manual rata-rata waktu terhitung 344.1 detik sedangkan menggunakan mesin irat bambu rata-rata waktu terhitung 233.3 detik. Mesin irat bambu ini perlu di kembangkan lagi sesuai dengan perkembangan di era modern ini.
\end{abstract}

Kata kunci : Rancang Bangun Mesin Irat Bambu, Tusuk Sate, Jeruji Sangkar Burung, Perbandingan Waktu.

\begin{abstract}
Making the bird cage bars manually is not very effective and efficient because it takes a long time and low precision and uniformity of size is not accurate. The method is used when the study is quality function development where such methods are used to determine the design and specifications of the machine in accordance with the wishes or demands of consumers in order to get results that match the wishes of consumers. This research analize technique using independent sample t-test using SPSS application comperative on the computer. Methods independent sample t-test is a method or procedure used to compare the average of two variables in the group, meaning that it is useful to carry out tests on two samples are paired. Based on the test results of independent sample t-test comparative that no changes are prominent on penyerutan time between 'penyerutan manually' using 'automatic penyerut machine'. The probability (sig) $0.000<0.05$ then Ho is rejected, or the average time results in a bamboo penyerutan manually by automatically varies significantly. This means that the results manually penyerutan time longer than the time using automated. In testing penyerutan bamboo with a length of $60 \mathrm{~cm}$ to manually average time of 344.1 seconds counted while using the machine bamboo irat average time of 233.3 seconds count. This bamboo irat machine needs to be developed further in accordance with the development of the modern era.
\end{abstract}

Keywords: Design of Machine Irat Bamboo, Plugs Sate, Bars Birdcage, Comparison of Time. 
Joko Winarno dan Rusdiyantoro : Rancang Bangun Mesin Irat Bambu Untuk Pembuatan Jeruji Sangkar Burung Dan Tusuk Sate

\section{PENDAHULUAN}

Orang Indonesia sudah lama memanfaatkan bambu untuk bangunan rumah, perabotan, alat pertanian, kerajinan, alat musik, dan makanan. Namun, bambu belum menjadi prioritas pengembangan dan masih dilihat sebagai "bahan milik kaum miskin yang cepat rusak". Karenanya, pemanfaatan bambu harus diintegrasikan dengan upaya pelestarian agar bambu tetap tersedia dalam jumlah yang cukup dan kualitas yang baik. Dengan pengelolaan bambu yang meliputi pembudidayaan, pengelolaan rumpun, dan pengembangan produk yang berkelanjutan dan ramah lingkungan(yanda aline,2012)

Adapun bentuk olahan bambu yaitu tusuk sate yang sangat sering di gunakan oleh para penjual makan yang membutuhkan alat tersebut. Terutama para penjual sosis/pentol di pusat perbelanjaan seperti mall membutuhkan tusuk sosis/pentol yang bagus dan halus untuk menikatkan nilai guna makanan tersebut.

Salah satu bentuk kerajinan dari bambu adalah sangkar burung. Dalam mebuat sangkar burung diperlukan jeruji-jeruji dari bambu yang kuat dan tidak mudah patah supaya jeruji bisa mengikuti model dari sangkar burung.Untuk membuat jeruji tersebut masih banyak yang manual menggunakan pisau terutama pada industri kecil. Pembuatan jeruji sangkar burung secara manual sangat tidak efektif dan efisien karena membutuhkan waktu yang lama dan presisi yang rendah serta keseragaman ukuran tidak akurat.

Meskipun sekarang sudah ada mesin penyerut bambu, tapi para pengerajin sangkar burung lebih suka membuat sendiri secara manual karena harga mesin penyerut bambu yang sangat mahal dan memerlukan tempat untuk meletakan mesin tersebut, para pengepul sangkar burung juga menjual jeruji sangkar burung yang siap untuk dipasang atau di rakit menjadi bentuk sangkar burung yang sempurna, tetapi para pengerajin masih suka membuat sendiri secara manual dengan alasan untuk menghemat biaya serta mendapat untung yang banyak.

Melihat banyaknya pecinta dan penghobi burung di Indonesia membuat para pengerajin sangkar sering kebanjiran pesanan sangkar burung, terkadang para pecinta dan penghobi burung pesan langsung ke pengerajin sangkar untuk menentukan sendiri model sangkar serta memilih kualitas bahan yang baik dan kuat.Karena mayoritas masyakat Indonesia mempunyai sifat yang ingin mendapatkan suatu barang dengan cepat, murah, dan mempunyai kualitas yang baik, membuat para pengerajin kewalahan sehinggah sering molor dalam penyelesaian pembuatan sangkar burung.Terutama pada kota-kota yang sering mengadakan even lomba burung yang megah dan sebagi adu gengsi para pecinta dan penghobi burung di kota-kota besar. Maka dari itu saya membuat penelitihan dengan judul Rancang Bangun Mesin Irat Bambu Untuk Pembuatan Jeruji Sangkar Burung Dan Tusuk Sate dan kegunaan lain. Karena mengingat bahaya serta tidak efisien dan tidak efektif dalam pembuatan jeruji sangkar burung secarama manual yang bisa menghambat proses produksi para pengerajin atau pengusaha sangkar burung.

\section{METODE}

\section{Rancangan Penelitian}

Penelitian merupakan proses yang sistematik, terkontrol, terdiri dari beberapa tahapan yang logis. Manfaat dari rancangan penelitian : sebagai kerangka operasional (blue -print), menegaskan kedalaman (intensitas) dan keluasan (ekstensitas) penelitan, memperkirakan kesulitan yang akan dihadapi dan rencana alternative penyelesaianya dan mengetahui keterbatasan atau kelemahan hasil penelitian (Gempur Santosa, dikutip dalam poniman 2012). Rancangan penelitian ini adalah rancangan penelitian eksperimen. Rancangan eksperimen yaitu suatu rancangan percobaan dengan setiap langkah tindakan yang terdefinisikan, sehingga informasi yang berhubungan dengan atau diperlukan suatu persoalan yang akan diteliti dapat dikumpulkan secara faktual (Juliansyah noor, dikutip dalam poniman 2012).

\section{Tempat Dan Waktu Penelitian}

Data yang dipergunakan dalam penelitian ini diperoleh dari penyebaran kuesioner kepada konsumen mesin irat bambu untuk pembuatan jeruji sangkar burung dan tusuk sate pada UKM pembuat tusuk sate atau pengerjin sangkar burung di wilayah krian dan sekitarnya.

Deskripsi Populasi dan Sampel Penelitian

1. Deskripsi Populasi

Populasi adalah wilayah generalisasi yang terdiri atas : objek/subjek yang mempunyai kualitas dan karakteristik tertentu yang ditetapkan oleh peneliti untuk dipelajari dan kemudian ditarik kesimpulan ( Sugiyono, dikutip dalam poniman 2012). 
Joko Winarno dan Rusdiyantoro : Rancang Bangun Mesin Irat Bambu Untuk Pembuatan Jeruji Sangkar Burung Dan Tusuk Sate

Populasi dalam Penelitian ini adalah UKM pembuat tusuk sate atau pengerajin sangkar burung wilayah krian dan sekitarnya terdata ada 10 UKM.

\section{Sampel Penelitian}

Sampel adalah bagian dari jumlah dan karakteristik yang dimiliki oleh populasi tersebut ( Sugiyono, dikutip dalam poniman 2012).

Sampel dalam penelitan ini adalah jumlah pengguna (konsumen) mesin irat bambu untuk pembuatan jeruji sangkar burung dan tusuk sate wilayah krian dan sekitarnya. Sedangkan teknik pengambilan sampling menggunakan purposive sampling yaitu teknik penentuan sampel dengan pertimbangan tertentu (Sugiyono, dikutip dalam poniman 2012).

Sampel pada penelitian ini bedasarkan waktu dalam membuat jeruji sangkar burung atau tusuk sate secara manual dan menggynakan mesin irat bambu yang akan diteliti. Dengan melakukan percobaan sebanyak 30 kali penyerutan.

\section{Quality Function Deployment}

a. Quality function deployment

QFD merupakan cara atau metode yang digunkan untuk pengembangan produk dengan memperhatikan tingkat kepentingan dan kepuasan konsumen.
Menurut ( Hari Purnomo, dikutip dalam poniman 2012). Quality function deployment merupakan suatu metode perencanaan dan pengembangan produk terstruktur yang memungkinkan tim pengembangan produk untuk menentukan secara jelas kepentingan dan kepuasan konsumen dan kemudian melakukan evalusi secara sistematis tentang kemampuanaya dalam menghasilkan produk untuk memuaskan konsumen. (poniman, 2012)

b. Kepentingan dan kepuasan konsumen

Kepentingan konsumen yaitu konsumen yang menentukan kualitas serta desain produk, sehingga perusahaan dalam membuat suatu produk harus dapat mempertimbangkan tingkat-tingkat kepentingan konsumen. Sedangkan kepuasan konsumen akan tercipta jika desain produk sesuai dengan keinginan konsumen serta merasakan hasil pekerjaaan sesuai dengan harapan atau bahkan melebihi harapan konsumen.

Kepuasan konsumen dalam penelitian ini adalah kepuasan terhadap mesin pembuat jeruji sangkar burung otomatis. Pada Tabel 1. menunjukan faktor -faktor yang mempengaruhi kepuasan konsumen.

Tabel 1. Faktor-Faktor Tingkat Kepentingan Dan Kepuasan Konsumen Terhadap Mesin Irat Bambu Untuk Pembuatan Jeruji Sangkar Burung Dan Tusuk Sate

\begin{tabular}{lcl}
\hline No & Kode Atribut & Atribut tingkat kepentingan dan kepuasan konsumen \\
\hline 1 & A1 & Alat tersebut dapat membentuk jeruji/tusuk sate dengan baik \\
2 & A2 & Hasil penyerutan halus \\
3 & A3 & Bisa diopersikan \\
4 & A4 & Sampah penyerutan kecil \\
5 & A5 & Dimensi mesin \\
6 & A6 & Berat mesin \\
7 & A7 & Kontruksi kuat dan rapi \\
8 & A8 & Mudah dipindah-pindahkan \\
9 & A9 & Mudah untuk dibongkar pasang \\
10 & A10 & Tempat sisa penyerutan \\
11 & A11 & Mudah dibersikan \\
12 & A12 & Material mudah dan murah \\
13 & A13 & Tahan lama \\
14 & A14 & Tingkat harga \\
\hline
\end{tabular}

\section{Metode Pengumpulan Data}

Metode pengumpulan data dalam penelitian ini untuk mengetahui tingkat kepentingan dan kepuasan konsumen terhadapmesin pembuat jeruji sangkar burung otomatis. Metode pengumpulan data menggunakan beberapa metode :

1. Interview (wawancara)

Wawancara digunakan sebagai teknik pengumpulan data apabila peneliti ingin menemukan permasalahan yang harus 
Joko Winarno dan Rusdiyantoro : Rancang Bangun Mesin Irat Bambu Untuk Pembuatan Jeruji Sangkar Burung Dan Tusuk Sate

diteliti. Hal ini dilakukan dalam bentuk pertanyaan yang diajukan ke nara sumber.

2. Observasi (pengamatan)

Observasi sebagai teknik pengumpulan data mempunyai ciri yang spesifik bila dibandingkan dengan teknik yang lain. Sutrisno Hadi (1986) mengemukakan bahwa, observasi merupakan suatu proses yang kompleks, suatu proses yang tersusun berbagai proses biologis dan psikhologis. Dua diantara yang terpenting adalah proses pengamatan dan ingatan. Teknik pengumpulan data dengan observasi digunakan bila, peneliti berkenaan dengan perilaku manusia, proses kerja, gejala gejala alam dan bila responden yang diamati tidak terlalu besar. Dalam suatu produksi, peneliti dapat mengamati bagaimana mesin dapat bekerja dengan baik. Penelitian ini akan di observasi tentang proses penyerutan bambu dari secara manual dan secara otomatis.

3. Kuesioner

Metode kuesioner adalah cara pengumpulan data dengan memberikan suatu daftar pertanyaan kepada responden untuk mendapatkan informasi tertentu. Penelitian ini menggunakan kuesioner dalam survei pelanggan. tujuan pokok kuesioner adalah untuk memeperoleh informasi yang relevan dari konsumen.

Dalam penelitian ini diajukan daftar pertanyaan dalam bentuk kuesioner. Kuesioner tahap awal teridiri 14 atribut yang disebarkan kepada 10 responden dan kuesioner ke -2 atribut hasil pengembangan yang di sebarkan kepada 10 responden yang sama. Adapun kuesioner ke-1 yang disebarkan dapat dilihat pada lampiran 1 . Sedangkan skala yang digunakan dalam kuesioner ini menggunakan skala 4 poin dengan meniadakan poin netral/biasa. Kuesioner ini menggunakan skala likert.

Tabel 2. Skala Tingkat Kepentingan

\begin{tabular}{ll}
\hline Tingkat Kepentingan & Poin \\
\hline Sangat penting & 4 \\
Penting & 3 \\
Tidak penting & 2 \\
Sangat tidak penting & 1 \\
\hline
\end{tabular}

Tabel 3. Skala Tingkat Kepuasan

\begin{tabular}{ll}
\hline Tingkat Kepuasan & Poin \\
\hline Sangat puas & 4 \\
Puas & 3
\end{tabular}

\begin{tabular}{ll} 
Tingkat Kepuasan & Poin \\
\hline Tidak puas & 2 \\
Sangat tidak puas & 1 \\
\hline
\end{tabular}

Dari hasil kuesioner responden ini dilakukan rekapitulasi data yang dibantu dengan menggunakan software microsoft exel 2007 dan uji intrumen penelitian.

\section{HASIL DAN PEMBAHASAN}

\section{Penyajian Data}

Penyajian data yang diperoleh dari hasil penelitian tingkat kepentingan dan kepuasan konsumen sebelum dilakukan pengembangan serta data hasil kepuasan terhadap mesin irat bambu untuk pembuatan jeruji sangkar burung dan tusuk sate disajikan dalam bentuk Tabel maupun histrogram.

Adapun data demografis responden dari UKM pengerajin sangkar burung di wilayah krian dan sekitarnya :

a. Tingkat pendidikan pengerajin sangkar terdiri dari :
1) $\mathrm{SD}: 6$ orang
2) SMP : 9 orang
3) SMA : 15 orang

b. Jenis kelamin pengerajin sangkar burung wilayah krian :

Tabel 4. Data Jenis Kelamin Pengerajin Sangkar Burung Wilayah Krian

\begin{tabular}{ccc}
\hline Jenis kelamin & Jumlah & prosentase \\
\hline Laki-laki & 30 & 100 \\
Perempuan & 0 & 0 \\
Total & 30 & 100 \\
\hline
\end{tabular}

Dari Tabel 4. dapat diketahui jenis kelamin pengerajin sangkar burung wilayah krian dan sekitarnya dengan mayoritas laki-laki yang menjadi pengerajin sangkar burung.

c. Usia responden pengerajin sangkar burung wilayah krian dan sekitarnya :

Tabel 5. Data Usia Responden Pengerajin Sangkar Burung Wilayah Krian Dan Sekitanya

\begin{tabular}{ccc}
\hline Usian responden & Jumlah & prosentase \\
\hline $15-25$ tahun & 3 & 10 \\
$26-40$ tahun & 18 & 60 \\
$41<$ & 9 & 30 \\
total & 30 & 100 \\
\hline
\end{tabular}

Dari Tabel 5. dapat diketahui usia responden paling banyak adalah usia 26-40 
Joko Winarno dan Rusdiyantoro : Rancang Bangun Mesin Irat Bambu Untuk Pembuatan Jeruji Sangkar Burung Dan Tusuk Sate

tahun sebesar $60 \%$, usia $41<$ sebesar $30 \%$, sedangkan usia 15-25 tahun sebesar 10\%.

d. Lama pekerjaan responden sebagai pengerajin sangkar burung :

Tabel 6. lama bekerja sebagi pengerajin sangkar burung di wilayah krian.

\begin{tabular}{ccc}
\hline Lama Pemakaian & Jumlah & Presentase \\
\hline$<1$ Tahun & 0 & 0 \\
$1-5$ Tahun & 13 & 44 \\
$6-10$ Tahun & 11 & 36 \\
$>10$ Tahun & 6 & 20 \\
Total & 30 & 100
\end{tabular}

Dari Tabel 6. sebagian besar lama pekerjaan sebagai pengerajin sangkar selama 1-5 tahun sebesar 44\%, selama 6-10 tahun sebesar 36\%, dan selama lebi lama dari 10 tahun sebesar $20 \%$.

e. Tingkat pendidikan pengerajin sangkar burung di wilayah krian
Tabel 7. tingkat pendidikan pengerajin sangkar burung wilayah krian.

\begin{tabular}{ccc}
\hline Pendidikan & Jumlah & prosentase \\
\hline SD & 6 & 20 \\
SMP & 9 & 30 \\
SMA & 15 & 50 \\
Total & 30 & 100 \\
\hline
\end{tabular}

Dari Tabel 7. sebagian besar pendidikan pengerajin sangkar burung di tingkat SMA sebesar 50\%, di tingkat SMP sebesar 30\%, di tingkat SD sebesar $20 \%$.

\section{Data Atribut Kepentingan dan kepuasan Konsumen}

Atribut tingkat kepentingan dan kepuasan pelanggan konsumen ditentukan dengan diskusi/ wawancara dengan tenaga ahli pendamping peneliti. Tools yang digunakan adalah cause effect diagram, dengan tools ini ditentukan faktor-faktor yang mempengaruhi kepuasaan pelanggan terhadap mesin irat bambu ini. Adapun data atribut tingkat kepentingan dan kepuasan pelanggan ditampilkan pada Tabel 8.

Tabel 8. Data atribut tingkat kepentingan dan kepuasan konsumen

\begin{tabular}{lcl}
\hline NO & Kode Atribut & Atribut tingkat kepentingan dan kepuasan konsumen \\
\hline 1 & A1 & Alat tersebut dapat membentuk jeruji/tusu sate dengan baik \\
2 & A2 & Hasil penyerutan halus \\
3 & A3 & Bisa diopersikan \\
4 & A4 & Sampah penyerutan kecil \\
5 & A5 & Dimensi mesin \\
6 & A6 & Berat mesin \\
7 & A7 & Kontruksi kuat dan rapi \\
8 & A8 & Mudah dipindah-pindahkan \\
9 & A9 & Mudah untuk dibongkar pasang \\
10 & A10 & Tempat sisa penyerutan \\
11 & A11 & Mudah dibersikan \\
12 & A12 & Material mudah dan murah \\
13 & A13 & Tahan lama \\
14 & A14 & Tingkat harga \\
\hline
\end{tabular}

Tabel 9. Hubungan Atribut Dengan Technical Realtiondata House Of Quality Fuction Deployment

\begin{tabular}{|c|c|c|c|c|c|}
\hline No & $\begin{array}{l}\text { Atribut tingkat } \\
\text { kepentingan }\end{array}$ & $\begin{array}{l}\text { Kode } \\
\text { Atribut }\end{array}$ & Technical Relations & $\begin{array}{l}\text { Kode } \\
\text { technical } \\
\text { relations }\end{array}$ & $\begin{array}{c}\text { Hubungan } \\
\text { Relations }\end{array}$ \\
\hline 1 & $\begin{array}{l}\text { Alat tersebut dapat } \\
\text { membentuk jeruji } \\
\text { sangkar dengan baik }\end{array}$ & A1 & Roll Pendorong & $\mathrm{T} 1$ & $\begin{array}{c}\text { A1 (T1, } \\
\text { T2,T3,T6) }\end{array}$ \\
\hline 2 & $\begin{array}{l}\text { Hasil penyerutan } \\
\text { halus }\end{array}$ & A2 & Pisau penyerut & $\mathrm{T} 2$ & A2 (T4) \\
\hline 3 & Bisa diopersikan & A3 & Roll Penarik & T3 & A3 (T5) \\
\hline 4 & $\begin{array}{l}\text { Sampah penyerutan } \\
\text { kecil }\end{array}$ & A4 & Ketajaman Pisau & $\mathrm{T} 4$ & A4 (T6) \\
\hline 5 & Ukuran hasil & A5 & Desain yang simpel & T5 & A5 (T7) \\
\hline
\end{tabular}


Joko Winarno dan Rusdiyantoro : Rancang Bangun Mesin Irat Bambu Untuk Pembuatan Jeruji Sangkar Burung Dan Tusuk Sate

\begin{tabular}{|c|c|c|c|c|c|}
\hline No & $\begin{array}{l}\text { Atribut tingkat } \\
\text { kepentingan }\end{array}$ & $\begin{array}{c}\text { Kode } \\
\text { Atribut }\end{array}$ & Technical Relations & $\begin{array}{c}\text { Kode } \\
\text { technical } \\
\text { relations }\end{array}$ & $\begin{array}{l}\text { Hubungan } \\
\text { Relations }\end{array}$ \\
\hline & penyerutan & & & & \\
\hline 6 & Berat mesin & A6 & Jarak antar pisau & T6 & A6 (T8) \\
\hline 7 & $\begin{array}{l}\text { Kontruksi kuat dan } \\
\text { rapi }\end{array}$ & A7 & $\begin{array}{l}\text { Jarak antara pisau } \\
\text { dan tempat bahan }\end{array}$ & $\mathrm{T} 7$ & A7 (T8,T9) \\
\hline 8 & $\begin{array}{l}\text { Mudah dipindah- } \\
\text { pindahkan }\end{array}$ & A8 & jenis material & $\mathrm{T} 8$ & A8 $(\mathrm{T} 8, \mathrm{~T} 10)$ \\
\hline 9 & $\begin{array}{l}\text { Mudah untuk } \\
\text { dibongkar pasang }\end{array}$ & A9 & Jenis sambungan & T9 & A9 (T9,T11) \\
\hline 10 & $\begin{array}{l}\text { Tempat sisa } \\
\text { penyerutan }\end{array}$ & A10 & $\begin{array}{l}\text { besar kecil dimensi } \\
\text { mesin }\end{array}$ & $\mathrm{T} 10$ & A10 (T12) \\
\hline 11 & Mudah dibersikan & A11 & $\begin{array}{l}\text { desain yang mudah } \\
\text { di bongkar pasang }\end{array}$ & $\mathrm{T} 11$ & $\begin{array}{c}\mathrm{A} 11 \\
(\mathrm{~T} 13, \mathrm{~T} 1, \mathrm{~T} 3, \mathrm{~T} 13 \\
\mathrm{T} 14)\end{array}$ \\
\hline 12 & $\begin{array}{l}\text { Material mudah dan } \\
\text { murah }\end{array}$ & A12 & $\begin{array}{l}\text { adanya bak } \\
\text { penampung }\end{array}$ & $\mathrm{T} 12$ & A12 (T15) \\
\hline 13 & Tahan lama & A13 & $\begin{array}{l}\text { Desain yang mudah } \\
\text { di bersihkan }\end{array}$ & T13 & $\begin{array}{c}\mathrm{A} 13 \\
(\mathrm{~T} 8, \mathrm{~T} 9, \mathrm{~T} 16)\end{array}$ \\
\hline 14 & Tingkat harga & A14 & $\begin{array}{l}\text { pisau mudah di } \\
\text { bongkar pasang } \\
\text { banyaknya suplayer } \\
\text { bahan } \\
\text { pengecatan }\end{array}$ & $\begin{array}{l}\text { T14 } \\
\text { T15 } \\
\text { T16 }\end{array}$ & A14 (T8,T5) \\
\hline
\end{tabular}

Data Perhitungan Mean tingkat kepentingan dan kepuasan

Dalam proses pengolahan data ini digunakan bantuan software Microsoft excel 2007. Tabel 4.2 menampilkan hasil perhitungan mean tiap-tiap atribut dari tingkat kepentingan dan kepuasan.
Nilai kepentingan menunjukkan kontribusi peran dari masing-masing atribut terhadap kepuasan pelanggan. Dari data hasil tersebut, diperoleh bahwa tingkat kepentingan tertinggi adalah alat tersebut dapat membentuk jeruji sangkar dengan baik,sampah penyerutan kecil,mudah dipindahkan,material mudah dan murah.

Tabel 10. Data Hasil Perhitungan Mean tingkat kepentingan dan kepuasan

\begin{tabular}{llllll}
\hline No & $\begin{array}{c}\text { Kode } \\
\text { Atribut }\end{array}$ & \multicolumn{1}{c}{ Atribut produk } & $\begin{array}{c}\text { Tingkat } \\
\text { Kepentingan }\end{array}$ & Prodet A & $\begin{array}{c}\text { Tingkat kepuasan } \\
\text { Target (prodct harapan) }\end{array}$ \\
\hline 1 & A1 & Alat tersebut dapat membentuk & 4 & 2 & 4 \\
& & jeruji/tusuk sate dengan baik & & 2 & 3 \\
2 & A2 & Hasil penyerutan halus & 3 & 3 & 3 \\
3 & A3 & Bisa diopersikan & 3 & 3 & 4 \\
4 & A4 & Sampah penyerutan kecil & 3 & 3 & 3 \\
5 & A5 & Dimensi mesin & 2 & 3 & 3 \\
6 & A6 & Berat mesin & 3 & 3 & 3 \\
7 & A7 & Kontruksi kuat dan rapi & 3 & 3 & 4 \\
8 & A8 & Mudah dipindah-pindahkan & 3 & 2 & 3 \\
9 & A9 & Mudah untuk dibongkar pasang & 2 & 3 & 3 \\
10 & A10 & Tempat sisa penyerutan & 3 & 2 & 3 \\
11 & A11 & Mudah dibersikan & 3 & 3 & 3 \\
12 & A12 & Material mudah dan murah & 3 & 2 & 4 \\
13 & A13 & Tahan lama & 4 & 2 & 4 \\
14 & A14 & Tingkat harga & 3 & 3 & 3 \\
\hline
\end{tabular}


Joko Winarno dan Rusdiyantoro : Rancang Bangun Mesin Irat Bambu Untuk Pembuatan Jeruji Sangkar Burung Dan Tusuk Sate

\begin{tabular}{cll}
\hline \multicolumn{2}{l}{ Keterangan: } \\
\hline Poin & Tingkat kepentingan & Tingkat kepuasan \\
\hline 1 & Sangat tidak penting & Sangat tidak puas \\
2 & Tidak penting & Tidak puas \\
3 & Penting & puas \\
4 & Sangat penting & Sangat puas \\
\hline
\end{tabular}

Hasil perhitungan mean pada tingkat kepentingan menunjukkan bahwa dari empat belas atribut ada 12 yang penting (nilai mean lebih besar atau sama dengan 3). Atribut yang penting adalah alat tersebut dapat membentuk jeruji/tusu sate dengan baik, hasil penyerutan halus, bisa diopersikan, sampah penyerutan kecil, berat mesin, kontruksi kuat dan rapi, mudah dipindah-pindahkan, tempat sisa penyerutan, mudah dibersikan, material mudah dan murah, tahan lama, tingkat harga.

Nilai kepuasan pelanggan terhadap produk saat ini ditetapkan sebagai performansi awal. Sedangkan hasil dari kepuasan produk harapan menunjukkan nilai kepuasan yang diharapkan yang akan menjadi nilai goal masing-masing atribut.

Hasil perhitungan mean pada tingkat kepuasan, bisa digambarkan dalam grafik line seperti ditampilkan pada Gambar 4.1. Dari grafik line tersebut dapat dilihat gap yang sangat signifikan antara kepuasan produk A dengan kepuasan produk yang diharapkan ( target ). Atribut-atribut yang harus dilakukan pengembangan yaitu pada atribut $\mathrm{A} 1, \mathrm{~A} 2, \mathrm{~A} 8$, A10, A12,dan A13 yang nilainya lebih besar.

Data atribut dengan nilai improvement ratio dari tinggi kerendah dapat dilihat pada Tabel 11.

Berdasar data pada Tabel 11 dapat dilihat bahwa ada 5 atribut kepuasan yang tingkat perubahannya sulit, 10 atribut kepuasan dengan tingkat perubahan mudah.

Tabel 11. Data urutan nilai improvement ratio

\begin{tabular}{cclcl}
\hline No & Kode atribut & \multicolumn{1}{c}{ Atribut produk } & Improvement ratio & Tingkat Perubahan \\
\hline 1 & A13 & Tahan lama & 2 & Sulit \\
2 & A14 & Tingkat harga & 2 & Sulit \\
3 & A8 & Mudah dipindah-pindahkan & 2 & Sulit \\
4 & A12 & Material mudah dan murah & 2 & Sulit \\
5 & A10 & tempat sisa penyerutan & 2 & Sulit \\
6 & A1 & Alat tersebut dapat membentuk & 1 & Mudah \\
7 & A2 & jeruji sangkar dengan baik & 1 & Mudah \\
8 & A6 & Berat penyerutan halus & 1 & Mudah \\
9 & A9 & Mudah untuk dibongkar pasang & 1 & Mudah \\
10 & A3 & Bisa diopersikan & 1 & Mudah \\
11 & A11 & Mudah dibersikan & 1 & Mudah \\
12 & A4 & Sampah penyerutan kecil & 1 & Mudah \\
13 & A5 & Ukuran hasil penyerutan & 1 & Mudah \\
14 & A7 & Kontruksi kuat dan rapi & 1 & Mudah \\
\hline
\end{tabular}

\subsection{Data Sales Point}

Penentuan sales point ditentukan dengan dasar nilai tingkat kepentingan. Nilai tingkat kepentingan dibagi menjadi tiga kelas, interval nilai kelas ditentukan seperti tercantum dalam Lampiran 5. Berdasarkan penghitungan data sales point tersebut dan data yang ditampilkan pada Tabel 4.4 maka terdapat 2 atribut yang memiliki pengaruh kepentingan yang kuat, 10 atribut memiliki pengaruh kepentingan yang sedang dan 2 atribut menunjukan tidak adanya pengaruh kepentingan . Urutan Sales point dari yang terbesar ke yang kecil dapat dilihat pada Tabel 4.4.

Tabel 12. Data Urutan Sales point

\begin{tabular}{cclcc}
\hline NO & $\begin{array}{c}\text { Kode } \\
\text { Atribut }\end{array}$ & \multicolumn{1}{c}{ Atribut Produk } & $\begin{array}{c}\text { Tingkat } \\
\text { Kepentingan }\end{array}$ & $\begin{array}{c}\text { Sales } \\
\text { Point }\end{array}$ \\
\hline 1 & A1 & $\begin{array}{l}\text { Alat tersebut dapat membentuk jeruji sangkar } \\
\text { dengan baik }\end{array}$ & 4 & 1,5 \\
2 & A13 & Tahan lama & 4 & 1,5 \\
3 & A2 & Hasil penyerutan halus & 3 & 1,2 \\
4 & A3 & Bisa diopersikan & 3 & 1,2 \\
\hline
\end{tabular}


Joko Winarno dan Rusdiyantoro : Rancang Bangun Mesin Irat Bambu Untuk Pembuatan Jeruji Sangkar Burung Dan Tusuk Sate

\begin{tabular}{cclcc}
\hline NO & $\begin{array}{c}\text { Kode } \\
\text { Atribut }\end{array}$ & \multicolumn{1}{c}{ Atribut Produk } & $\begin{array}{c}\text { Tingkat } \\
\text { Kepentingan }\end{array}$ & $\begin{array}{c}\text { Sales } \\
\text { Point }\end{array}$ \\
\hline 5 & A5 & Ukuran hasil penyerutan & 3 & 1,2 \\
6 & A6 & Berat mesin & 3 & 1,2 \\
7 & A7 & Kontruksi kuat dan rapi & 3 & 1,2 \\
8 & A8 & Mudah dipindah-pindahkan & 3 & 1,2 \\
9 & A10 & tempat sisa penyerutan & 3 & 1,2 \\
10 & A11 & Mudah dibersikan & 3 & 1,2 \\
11 & A12 & Material mudah dan murah & 3 & 1,2 \\
12 & A14 & Tingkat harga & 3 & 1,2 \\
13 & A4 & Sampah penyerutan kecil & 2 & 1 \\
14 & A9 & Mudah untuk dibongkar pasang & 2 & 1 \\
\hline
\end{tabular}

1.2. Data Penghitungan Raw Weight

Penghitungan raw weight dengan menggunakan persamaan

raw weight = importance rating $\mathrm{x}$ improvemen $\mathrm{t}$ ratio $\mathrm{x}$ sales point

Kemudian dilanjutkan dengan perhitungan normalized raw weight dengan persamaan

$$
\text { normalized raw weight }=\frac{\text { raw weight }}{\text { total raw weight }} \times 100 \%
$$

Urutan atribut dengan nilai raw weight tinggi ke rendah ditampilkan pada Tabel 13. Nilai raw weight diperoleh dari perkalian tiga komponen yaitu tingkat kepentingan, improvement ratio dan sales point. Nilai raw weight dapat digunakan sebagai dasar dalam menentukan atribut produk yang harus dikembangkan karena komponen yang ada di dalamnya cukup menyeluruh. Semakin tinggi nilai maka atribut tersebut mendapatkan prioritas yang lebih utama.

Tabel 13. Data urutan raw weight dan normalized raw weight

\begin{tabular}{cclcc}
\hline No & $\begin{array}{c}\text { Kode } \\
\text { atribut }\end{array}$ & \multicolumn{1}{c}{ Atribut produk } & Raw weight & Normalized Raw Weight \\
\hline 1 & A13 & Tahan lama & 12 & $16 \%$ \\
2 & A8 & Mudah dipindah-pindahkan & 7 & $10 \%$ \\
3 & A10 & tempat sisa penyerutan & 7 & $10 \%$ \\
4 & A12 & Material mudah dan murah & 7 & $10 \%$ \\
5 & A14 & Tingkat harga & 7 & $10 \%$ \\
6 & A1 & Alat tersebut dapat menggiling & 6 & $8 \%$ \\
7 & A6 & Berat mesin & 4 & $6 \%$ \\
8 & A2 & Hasil penyerutan halus & 4 & $5 \%$ \\
9 & A3 & Bisa diopersikan & 4 & $5 \%$ \\
10 & A7 & Kontruksi kuat dan rapi & 4 & $5 \%$ \\
11 & A11 & Mudah dibersihkan & 4 & $5 \%$ \\
12 & A4 & Sampah penyerutan kecil & 3 & $4 \%$ \\
13 & A5 & Ukuran hasil penyerutan & 2 & $3 \%$ \\
14 & A9 & Mudah untuk dibongkar pasang & 2 & $3 \%$ \\
& total & & 75 & $100 \%$ \\
\hline
\end{tabular}

Berdasarkan Tabel 13. bahwa terdapat 5 atribut yang memiliki prosentase diatas $8 \%$, penghitungan row weigh ini sebagai dasar pertimbangan untuk pengembangan atribut produk yang akan dikembangan dari atribut yang memiliki nilai tertinggi yaitu atribut Tahan lama, Bentuk meja mesin, Tingkat harga, Mudah dipindah-pindahkan, material mudah dan murah.
1.2.1. Data Penghitungan Absolute Importance dan Relative Importance

Nilai absolute importance yang tinggi menunjukkan bahwa technical requirement tersebut memiliki pengaruh yang besar terhadap atribut-atribut produk. House of Quality Function Deployment dapat dilihat pada lampiran 6. 
Tabel 14. Data urutan absolut score dan relative score

\begin{tabular}{cclcc}
\hline No. & Kode technical relations & \multicolumn{1}{c}{ Technical Relations } & absolute score & $\begin{array}{c}\text { relative } \\
\text { score }\end{array}$ \\
\hline 1 & T8 & jenis material & 81 & 20 \\
2 & T2 & Pisau penyerut & 45 & 11 \\
3 & T9 & Jenis sambungan & 42 & 10 \\
4 & T3 & Roll Penarik & 39 & 10 \\
5 & T1 & Roll Pendorong & 39 & 9 \\
6 & T4 & Ketajaman Pisau & 36 & 8 \\
7 & T7 & Jarak antara pisau dan tempat bahan & 27 & 6 \\
8 & T6 & Jarak antar pisau & 27 & 6 \\
9 & T10 & besar kecil dimensi mesin & 27 & 6 \\
10 & T12 & adanya bak penampung & 27 & 6 \\
11 & T16 & pengecatan & 18 & 4 \\
12 & T13 & Desain yang mudah di bersihkan & 9 & 1 \\
13 & T15 & banyaknya suplayer bahan & 9 & 1 \\
14 & T5 & Desain yang simpel & 5 & 1 \\
& T11 & desain yang mudah di bongkar pasang & 3 & 1 \\
16 & T14 & pisau mudah di bongkar pasang & 3 & 1 \\
\hline
\end{tabular}

Berdasarkan Tabel 14. dapat dilihat nilai absolute score dari yang tertinggi sampe dengan yang terendah. Nilai absolut tertinggi yaitu atribut jenis material, pisau penyerut jenis sambungan,roll penarik, dan roll pendorong.
Setelah melukan analisan tingkat kepentingan konsumen maka dapat diambil desain pengembangan dari desain alternatif seperti gambar berikut ini :
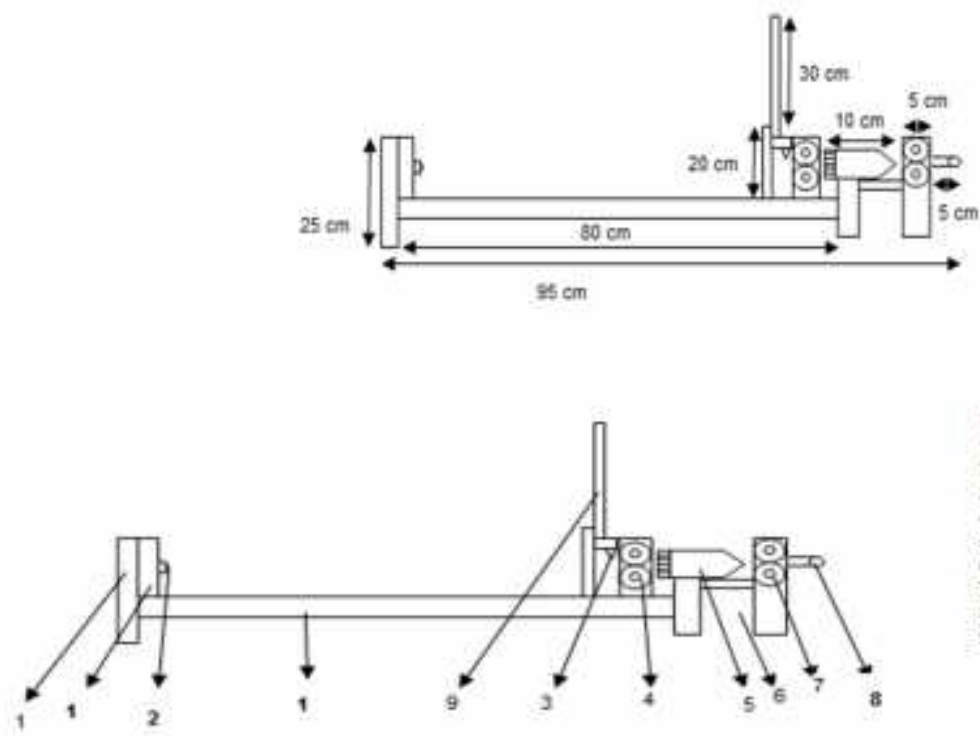

keterangan : 1.rangka mesin 2.tombol swit 3.pisau pemotong 4. roit penarik 5.pisau penyerut 6.motor de Troll pendorong S.lubang input bahan
9.tuas pemotong

Gambar 4.2 Desain Pengembangan Mesin Irat Bambu Untuk Pembuatan Jeruji Sangkar Burung Dan Tusuk Sate 
Joko Winarno dan Rusdiyantoro : Rancang Bangun Mesin Irat Bambu Untuk Pembuatan Jeruji Sangkar Burung Dan Tusuk Sate

Analisis Data

Independent Samples Test

\begin{tabular}{|c|c|c|c|c|c|c|c|c|c|c|}
\hline \multicolumn{2}{|c|}{$\begin{array}{c}\text { Levene's Test for } \\
\text { Equality of Variances }\end{array}$} & \multicolumn{9}{|c|}{ t-test for Equality of Means } \\
\hline \multirow{4}{*}{$\begin{array}{l}\text { Kebutuhan } \\
\text { Waktu }\end{array}$} & \multirow{4}{*}{$\begin{array}{l}\text { Equal } \\
\text { variances } \\
\text { assumed } \\
\text { Equal } \\
\text { variances } \\
\text { not } \\
\text { assumed }\end{array}$} & \multirow[t]{2}{*}{$\mathrm{F}$} & \multirow[t]{2}{*}{ Sig. } & \multirow[t]{2}{*}{$\mathrm{t}$} & \multirow[t]{2}{*}{$\mathrm{df}$} & \multirow[t]{2}{*}{$\begin{array}{l}\text { Sig. } \\
(2- \\
\text { tailed })\end{array}$} & \multirow[t]{2}{*}{$\begin{array}{l}\text { Mean } \\
\text { Difference }\end{array}$} & \multirow[t]{2}{*}{$\begin{array}{l}\text { Std. Error } \\
\text { Difference }\end{array}$} & \multicolumn{2}{|c|}{$\begin{array}{l}\text { 95\% Confidence } \\
\text { Interval of the } \\
\text { Difference }\end{array}$} \\
\hline & & & & & & & & & Lower & Upper \\
\hline & & 10.353 & .002 & 45.772 & 58 & .000 & 110.867 & 2.422 & 106.018 & 115.715 \\
\hline & & & & 45.772 & 39.354 & .000 & 110.867 & 2.422 & 105.969 & 115.764 \\
\hline
\end{tabular}

Hipotesis :

Ho $=$ rata-rata hasil produktivitas pengujian sama

$\mathrm{Ha}=$ rata-rata hasil kedua pengujian

produktivitas tidak sama

Pengambilan keputusan :

Berdasarkan perbandingan nilai probabilitas (sig)

Jika probabilitas > 0,05 maka Ho diterima

Jika probabilitas < 0,05 maka Ho ditolak

Keputusan :

Terlihat bahwa $\mathrm{t}$ hitung adalah 45.77 dengan nilai probabilitas (sig) 0,000. Oleh karena probabilitas (sig) 0,000 < 0,05 maka Ho ditolak, atau rata-rata hasil waktu dalam penyerutan bambu secara manual dengan secara otomatis berbeda signifikan. Artinya hasil waktu penyerutan secara manual lebih lama dibandingkan dengan waktu menggunakan otomatis.

Dalam analisa QFD ada beberapa atribut yang memang menjadi keinginan konsumen. Pada data improvement ratio terdapat 5 atribut yang tigkat perubahannya sulit seperti tahan lama, tingkat harga, mudah di pindahpindahkan, material mudah dan murah, tempat sisa penyerutan. Pada data sales point terdapat 2 atribut yang nilai sales poinnya tertinggi yaitu alat tersebut dapat membentuk jeruji sangkar dengan baik dan tahan lama. Pada data urutan raw weight dan normalized raw weight terdapat 5 atribut yang raw weightnya diatas 6 dan 5 atribut yang normalized raw weightnya diatas $8 \%$ yaitu atribut tahan lama, mudah dipindahpindahkan, tempat sisa penyerutan, material mudah dan murah, serta tingkat harga. Pada data urutan absolut score dan relative score terdapat 6 technical relation yang absolute scorenya diatas 35 yaitu jenis material, pisau penyerut, jenis sambungan, roll penarik, roll pendorong, serta ketajaman pisau dan terdapat 5 technical relation yang relative scorenya di atas
8 yaitu jenis material, pisau penyerut, jenis sambungan, roll penarik, serta roll pendorong. Dalam penyerutan bambu dengan panjang 60 $\mathrm{cm}$ secara manual dengan $30 \mathrm{kali}$ penyerutan dengan waktu rata-rata 344.1 detik, sedangkan dengan mengunakan mesin irat bambu dengan penyerutan 30 kali dengan panjang bambu 60 cm dengan rata-rata 233.23 detik. Bedasarkan uji independent sample t-test menunjukan bahwa ada penikatan, dengan nilai probabilitas $0,000<0,05$ maka Ho ditolak, artinya terjadi perubahan waktu yang sangat signifikan antara secara manual dan secara otomatis.

\section{KESIMPULAN}

Terdapat 14 atribut produk mesin irat bambu yang berpengaruh terhadap kepuasan pelanggan yaitu alat tersebut dapat membentuk sangkar dengan baik, bisa dioperasikan, hasil penyerutan halus, dimensi mesin, berat mesin, kontruksi kuat dan rapi, mudah dipindahpindahkan, mudah untuk dibongkar pasang, tempat sisa penyerutan, material mudah dan murah, tahan lama, mudah dibersihkan dan tingkat harga. Terdapat 14 atribut tingkat penting menurut pelanggan yaitu alat tersebut dapat membentuk sangkar dengan baik, bisa dioperasikan, hasil penyerutan halus, dimensi mesin, berat mesin, kontruksi kuat dan rapi, mudah dipindah-pindahkan, mudah untuk dibongkar pasang, tempat sisa penyerutan, material mudah dan murah, tahan lama, mudah dibersihkan dan tingkat harga. Dalam rangka mengembangkan produk yang memenuhi kepuasan pelanggan maka pembuatan produk disesuaikan dengan keinginan atau pendapat dari konsumen penggunaan pisau penyerut yang berbentuk snei, adanyaa alat untuk menentukan tebal jeruji yang presisi, alat ukur panjang jeruji serta pemotong hasil jeruji yang sesuai keinginan pengguna. Dalam penyerutan bambu 
Joko Winarno dan Rusdiyantoro : Rancang Bangun Mesin Irat Bambu Untuk Pembuatan Jeruji Sangkar Burung Dan Tusuk Sate

dengan panjang $60 \mathrm{~cm}$ secara manual dengan 30 kali penyerutan dengan waktu rata-rata 344.1 detik, sedangkan dengan mengunakan mesin irat bambu dengan penyerutan 30 kali dengan panjang bambu $60 \mathrm{~cm}$ dengan rata-rata 233.23 detik. Dengan selisih 110.87 detik dapat disimpulkan bahwa proses penyerutan menggunakan mesin yang saya buat lebuh cepat 110.87 detik dari proses manual.

\section{UCAPAN TERIMA KASIH}

Ucapan terima kasih dan penghargaan perlu penulis sampaikan kepada berbagai pihak yang telah memberikan bantuan berupa bimbingan, arahan, saran, dukungan dan kemudahan sejak awal sampai akhir penyusunan Tugas Akhir ini.

\section{DAFTAR PUSTAKA}

Kaleka, Norbertus. 2014. Kreasi Sangkar Burung. Arcitra. Yogyakarta.

Morisco. 1999. Rekayasa Bambu. Nafiri Offset . Yogyakarta.

-2008. Teknologi Bambu. Diktat kuliah Magister Teknik Bahan Bangunan Jurusan Teknik Sipil dan Lingkungan UGM.

Poniman, 2012. Skripsi tugas akhir disain pembuatan alat penggiling daging dengan quality function deployment. Surabaya.

Prayitno. 2008. Teknologi Kayu. Diktat Kuliah Magister Teknik Bahan Bangunan Jurusan Teknik Sipil dan Lingkungan UGM.

Wijaya,Florentinus Rendriarta. 2003. Pengaruh Pengawetan dengan Metode Perendaman dalam Larutan Prusi terhadap Karakteristik Bambu Ampel (Bambusa vulgaris Schrad). Tugas Akhir pada Jurusan Teknik Sipil dan Lingkungan UGM. 